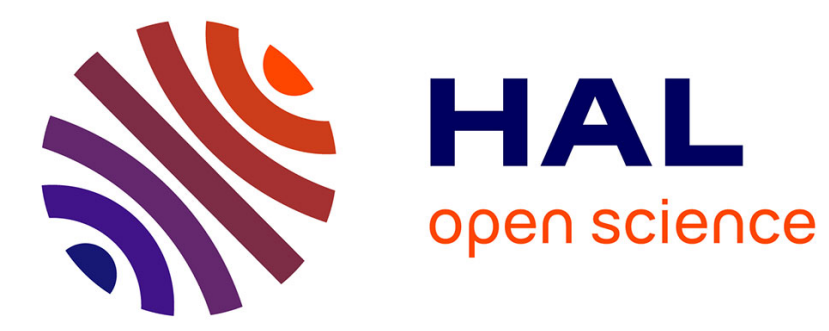

\title{
Phenology and roosting habits of the Central European grey long-eared bat (Fischer 1829)
}

\author{
Agnes Scheunert, Andreas Zahn, Andreas Kiefer
}

\section{To cite this version:}

Agnes Scheunert, Andreas Zahn, Andreas Kiefer. Phenology and roosting habits of the Central European grey long-eared bat (Fischer 1829). European Journal of Wildlife Research, 2009, 56 (3), pp.435-442. 10.1007/s10344-009-0333-9 . hal-00535262

\section{HAL Id: hal-00535262 \\ https://hal.science/hal-00535262}

Submitted on 11 Nov 2010

HAL is a multi-disciplinary open access archive for the deposit and dissemination of scientific research documents, whether they are published or not. The documents may come from teaching and research institutions in France or abroad, or from public or private research centers.
L'archive ouverte pluridisciplinaire HAL, est destinée au dépôt et à la diffusion de documents scientifiques de niveau recherche, publiés ou non, émanant des établissements d'enseignement et de recherche français ou étrangers, des laboratoires publics ou privés. 


\title{
Phenology and roosting habits of the Central European grey long-eared bat Plecotus austriacus (Fischer 1829)
}

\author{
Agnes Scheunert • Andreas Zahn • Andreas Kiefer
}

Received: 1 April 2009 /Revised: 28 September 2009 /Accepted: 1 October 2009/Published online: 17 October 2009

(C) Springer-Verlag 2009

\begin{abstract}
The authors monitored five maternity colonies of Plecotus austriacus to obtain data about phenology, roosting, and emergence behaviour. The bats occupied their roosts between April and October, with maximum colony sizes in August. Roosting sites in the attic's roof ridge and temperatures of $20-25^{\circ} \mathrm{C}$ were favoured. Also considering the small colony (maximum 59) and cluster sizes (maximum 13 bats), P. austriacus behaved less thermophilic than other attic-dwelling species. During low temperatures, the bats chose small crevice-like roosting sites to compensate for that; during daytime, many bats remained hidden in crevices. Emergence began approximately $30 \mathrm{~min}$ after sunset; the bats used multiple, preferably crevice-like openings. $P$. austriacus left its summer roosts comparatively late; renovation works should, therefore, not start before November. For monitoring purposes, we recommend two to three emergence countings outside the attics in early August during warm weather, alongside two attic inspections $1-2 \mathrm{~h}$ before emergence for offspring monitoring.
\end{abstract}

Communicated by H. Kierdorf

A. Scheunert $(\bowtie)$

Department Biologie I,

Ludwig-Maximilians-Universität München,

Menzinger Str,

München, Germany

e-mail: agnes.scheunert@1rz.uni-muenchen.de

A. Zahn

Department Biologie II,

Ludwig-Maximilians-Universität München,

Martinsried, Germany

A. Kiefer

Department Ecology, Johannes Gutenberg-Universität Mainz,

Mainz, Germany
Keywords Plecotus austriacus · Phenology · Roosting behaviour $\cdot$ Thermoregulation $\cdot$ Conservation $\cdot$ Emergence

\section{Introduction}

The grey long-eared bat Plecotus austriacus is a severely endangered species in Germany (Bundesamt für Naturschutz 1998) with a presumably negative population growth (Rudolf 2004). Studies on the ecology and behaviour of $P$. austriacus are scarce (Braun and Häussler 2003), despite the fact that basic knowledge is needed in order to develop adequate conservation methods. Such a kind of information is also legally required for implementation of the European "Fauna Flora Habitat (FFH)" directive, which includes reports about the situation of this species listed in appendix IV of this legislation.

It is known that Central European maternity colonies of P. austriacus settle in buildings and especially in attics (Hanák 1969; Horácek 1975). Most colonies consist of less than 50 individuals (Braun and Häussler 2003; Rudolf 2004). The summer roosts concentrate in areas of warmer climate, but during winter, the species tolerates comparatively low temperatures and is even found hibernating in attics (Stebbings 1970). Kiefer (1996) investigated the roosting ecology and hunting behaviour of colonies of $P$. austriacus. According to his study, hunting times vary considerably and nighttime flight activity is reduced by low temperatures and bad weather conditions. Various hunting areas are used during one night (preferably grassland, glades, and orchard meadows); hunting in trees can be observed frequently. In the study, P. austriacus favoured roosting in the ridge of the attic and chose different roosting sites due to thermoregulatory reasons or placement of the offspring (better possibilities for young bats to grab hold). 
Comparative studies on $P$. austriacus and its sister species Plecotus auritus were made by Horácek (1975). The author stated as main difference between the two species the partiality of $P$. auritus to crevice-like roosting sites in the summer roosts, a feature which is much more pronounced in this species than in P. austriacus. Furthermore, he mentioned the affinity to buildings for roosting and open landscapes for hunting in P. austriacus, whereas $P$. auritus also uses tree cavities and mainly hunts in woodland. However, little is still known about roosting behaviour, temperature preferences in the roosts, emergence habits, and phenology of Central European colonies of $P$. austriacus.

In this study, we present data about the phenology of $P$. austriacus in Bavaria, achieved from five maternity colonies at five localities. We studied how roosting sites are chosen in dependence of season, daytime, reproductive cycle, and temperature; describe emergence and swarming behaviour; and suggest methods to determine colony sizes.

\section{Materials and methods}

\section{Localities}

We studied five maternity colonies of $P$. austriacus all situated in the attics of church buildings in villages north of Munich (three of them in the administrative district Neuburg-Schrobenhausen, one each in Freising and Erding). Attic size varied between 112 and $396 \mathrm{~m}^{2}$ and altitude between 415 and $470 \mathrm{~m}$. In all cases, the apsis pointed east. The colonies were visited 85 times between 13 April 2004 and 03 November 2004.

Five different types of roosting sites in attics and one in clock towers were characterised as follows (Fig. 1):

1) ridge-corner: bats roost in the upmost corner where the roof ridge touches the side walls.

2) ridge-open: bats hang freely at the roof ridge or up to $2 \mathrm{~m}$ below at tiles or beams.

3) ridge-crevice: bats roost in narrow crevices between beams or tiles at the ridge and up to $2 \mathrm{~m}$ below (there e.g. in wooden laggings in the apsis; in the space on top of rafters and pillars; in gaps in tenon dowel joints of beams).

4) attic-open: bats hang freely visible more than $2 \mathrm{~m}$ beneath the ridge at tiles or beams.

5) attic-gaps: bats roost in narrow crevices more than $2 \mathrm{~m}$ beneath the ridge, e.g. where the roof touches the side walls or in crevices between wood and brick wall (similar to "ridge-corner").

6) clock tower: bats roost in the upper parts of the clock tower above the bells, most often hanging from beams.
Behavioural observations

Behavioural observations were carried out in all five maternity colonies. We monitored the emergence behaviour of the bats, either from the outside (48 times) or in the attic itself (eight times) and visited the attics during the day (28 times, between 9:00 a.m. and 5:00 p.m.) or in the evening (42 times, between 5:00 p.m. and 10:30 p.m.) to count present bats and for behavioural observations. On 4 days, the behaviour of one colony was observed during a whole day (09:30 a.m. $-10: 30$ p.m.) and three times during a whole night (9:00 p.m.-6:00 a.m.). Regarding behavioural observations, we distinguished between close physical contact (dense clusters of bats), loose physical contact (bats touched each other slightly or hung in distances below $0.5 \mathrm{~cm}$ ), and no physical contact (distance between the animals $>0.5 \mathrm{~cm}$ ).

We regarded as "swarming" when the bats displayed circling flight activities in the roost and in front of the emergence openings (inside and outside the attic) before emergence or after return; also when bats circuited around roosting sites.

To compare the behaviour of bats in different seasons, we defined five periods: "post-hibernation" (13 April-31 May), "prelactation" (01 June-28 June; period when the colony is complete and before the young are born), "lactation" (29 June-28 July; birth and lactation), "fledging" (29 July-31 August, fledging of the juveniles), and "pre-hibernation" (01 September-03 November).

\section{Physical measurements}

Thirty-six bats were captured by a hand net to determine sex, age, and reproductive status. The age of juvenile bats was roughly estimated by body size and development status of the wings. Temperature values were collected outside the churches as well as directly at roosting sites in the attics and the clock towers. For that, we used a mechanical longdistance thermograph with two temperature sensors on approximately 6-m-long extension cables and several Thermochron iButtons (Dallas Semiconductor), which obtain temperature data at selectable time intervals and store them for future analysis with the iButton-TMEX software (version 3.21 beta). For sporadic measurements at various points of the attic, a thermometer with a temperature sensor on a 3-m extension was used.

In order to facilitate the comparison of colonies differing in size, the number of bats counted was expressed as percent of the maximum number of animals recorded in the respective colony, with the number of bats given as "percent of the yearly maximum". Statistic tests (nonparametric significance test: Mann-Whitney U; correlation test: Pearson correlation coefficient) were conducted with the software "SPSS for Windows", version 12.0.1. 
Fig. 1 P. austriacus bats at four of the six roosting site types. From left to right Ridge-cornerpicture taken looking upwards, the bat sitting in the roof ridge above the wall shared by attic and clock tower. Ridge-openbat hanging from a roof lath approximately $30 \mathrm{~cm}$ below the ridge. Ridge-crevice - bat sitting between ridge and rafter. Atticgaps-picture taken looking slantly upwards, bats sitting in a gap between walls and beam
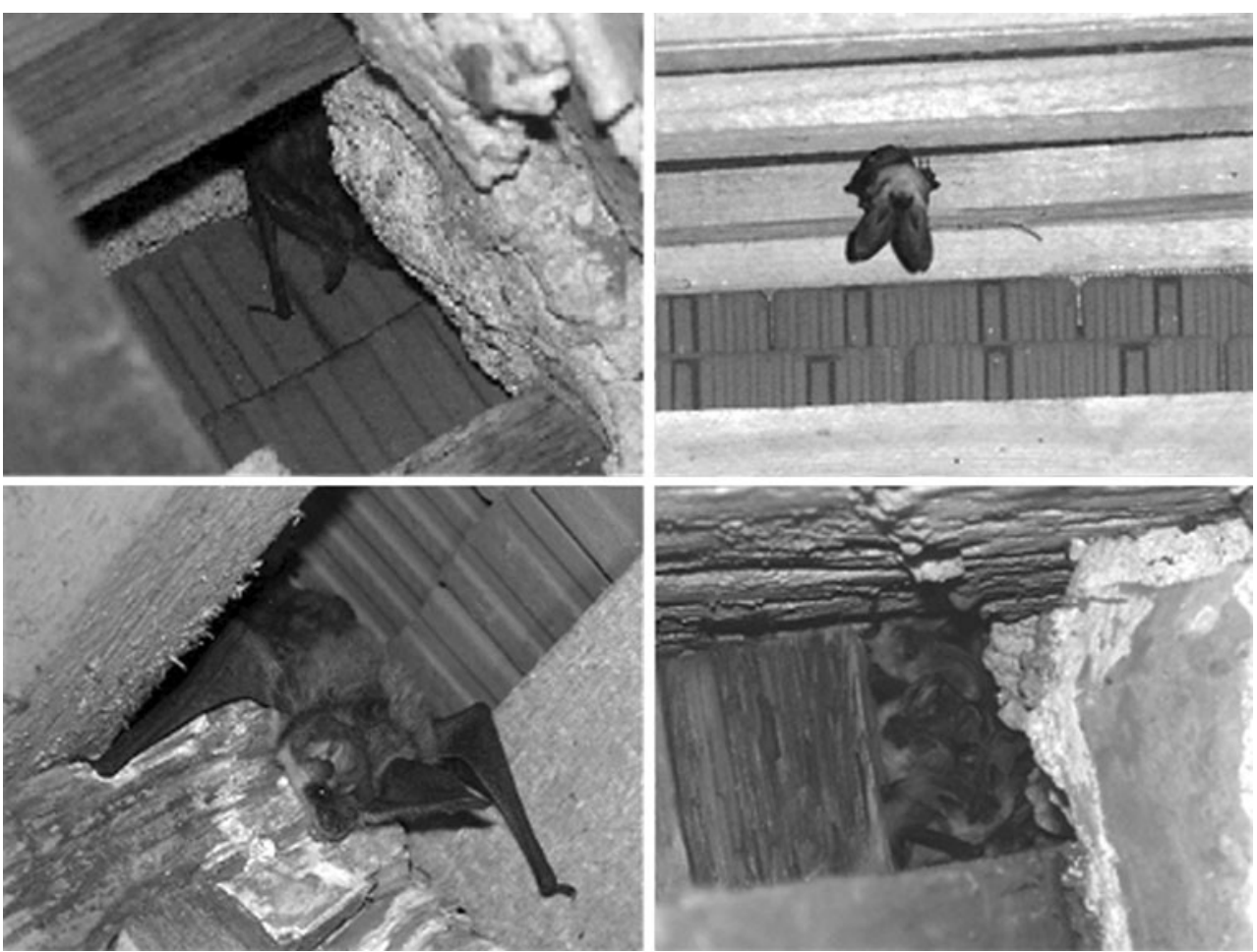

During control visits, we distinguished between "good weather conditions" (days without rain, with sunshine at least for $7 \mathrm{~h}$ ) and "bad weather conditions" (sunshine $<7 \mathrm{~h}$, with or without rain). To describe the phenology of the colonies, only data obtained during "good weather conditions" were taken into account. If two countings were conducted in a colony during 1 day, the higher number was used.

\section{Results}

\section{Phenology}

The first bats or fresh faecal pellets, indicating the return of the colonies into their summer roosts, were found between 22 April and 06 May. Numbers of bats continuously increased until maximum colony sizes $(10,17,21,42$, and 59 bats) were recorded in August, between 16/08 and 30/08 (seasonal period "fledging", see Fig. 2). In the course of the day, maximum numbers of animals were always counted in the evening, about $1 \mathrm{~h}$ before emergence.

The last bats were seen in mid-September in two colonies; in the three others, the animals were still present during October, with last individuals being observed at 23 October. After that date, no P. austriacus bats could be found, though it cannot be excluded that some of the animals may have been hidden in crevices of walls or beams. In three of the five colonies, the numbers of counted bats varied considerably even within short time intervals, indicating that sometimes a part of the colony might have been absent from the roost (Fig. 3).

Our captures indicated that adult males are rare in maternity colonies. Only three of 38 caught bats were adult males. One was caught in April (22/04), the other two in September (17/09). The first infant was found at the end of June (29/06); most females gave birth in early July. At the end of July, several young bats could be observed. Their estimated age varied between 1 and 4 weeks, suggesting that not all of the offspring was born at the same time. However, young bats were difficult to detect at the roosting sites. Therefore, it was not possible to make a reliable estimation on the ratio adults/juveniles. At 29 July, at the

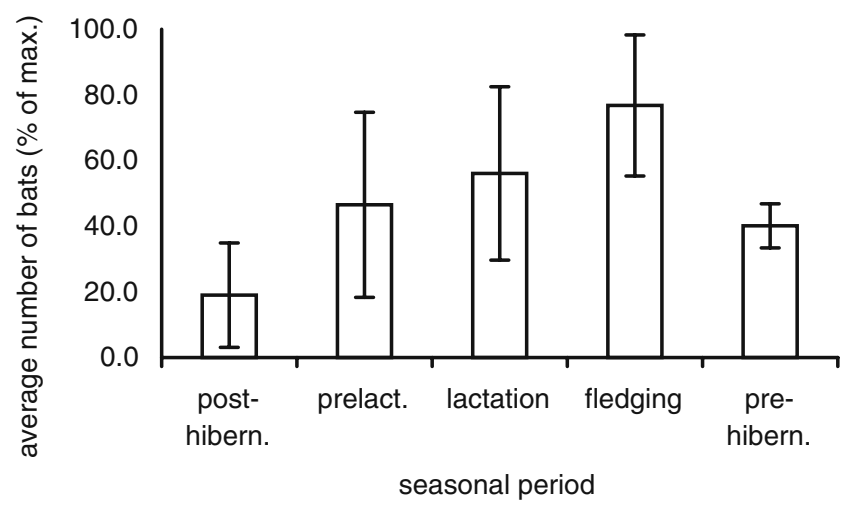

Fig. 2 Average colony sizes during the study period, given in percent of the maximum size of each colony, as means of all colonies with standard deviation. Posthibernation 13 April-31 May, prelactation 01 June-28 June, lactation 29 June-28 July, fledging 29 July-31 August, prehibernation 01 September-03 November 


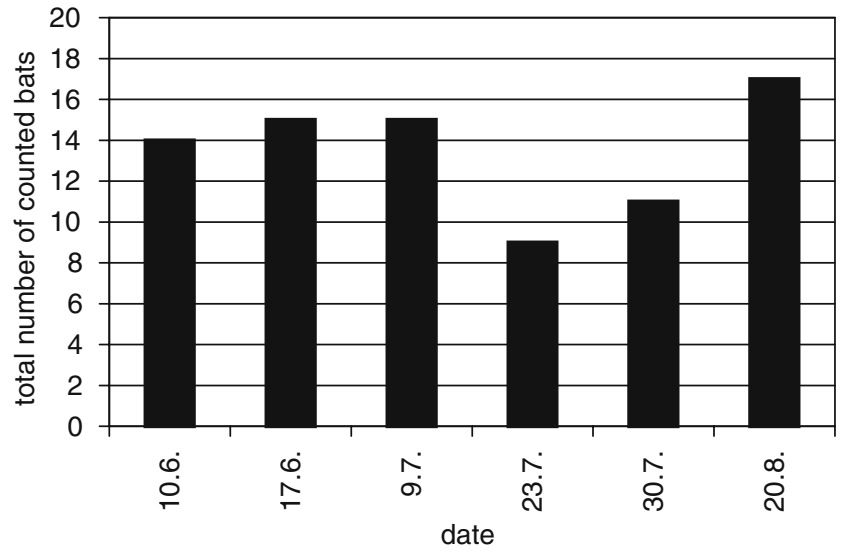

Fig. 3 Variation in colony size during prelactation, lactation, and postlactation periods, exemplified by one colony. Noticeable low numbers of bats on 23 July (nine bats) and 30 July (11 bats) were recorded at the time when numbers were supposed to be rising due to the fledging of the offspring

age of approximately 4 weeks, the first fledged young were observed emerging in the evening. During prehibernation, $60 \%$ of 15 captured bats were juveniles, indicating that they tend to stay longer in the summer roosts than the adults.

\section{Roosting sites}

The five studied colonies included six to 16 roosting sites (12 on average) in the attic and clock tower. There was a weak positive correlation between the recorded maximum numbers of bats in the colony and the number of roosting sites used, but the correlation was not significant (Pearson correlation coefficieny value $r=0.62, p=0.132$ ). Ten percent of all sites were found in the clock tower, the others in the attic. The roof ridge (open sites or crevices) was the most intensively used site overall, with up to $81 \%$ of the observed individuals found there (Fig. 4). The roof truss of the clock tower, which warms up very quickly in sunshine, was mainly used during post- and prehibernation periods when $33 \%$ and $19 \%$, respectively, of the individuals were found there. Only during fledging was the roosting type "attic-open" sporadically used (1\%). In some cases, special roosting sites in crevices in the walls were found, being used only during the first few weeks after parturition.

In the evening, the number of bats observed outside crevices increased considerably; the bats obviously preferred different roosting sites during the course of the day. Crevices were favoured before 5:00 p.m. (61\% of all observed bats used those sites, whereas 39\% hung freely visible), free sites in the ridge after 5:00 p.m. (60\% freely visible, $40 \%$ in crevices), and also when nighttime activity (which is, from $45 \mathrm{~min}$ before emergence) started (63\% freely visible, $37 \%$ in crevices). In contrast to adult bats, nonvolant juveniles strongly preferred crevice-like roosting sites at all times of the day: $95 \%$ of them were found in gaps and crevices.

At four of the six roosting site types (those mainly used by the bats), regular temperature measurements were conducted in order to gain information about their thermal profiles and in the following to identify the temperature preferences of $P$. austriacus. Within the study period, the highest temperatures were measured in August and September, and the lowest during posthibernation period, but relative differences between roosting site categories stayed the same. The highest average temperatures, but also the highest and lowest values ever measured, were recorded in crevices in the roof ridge (Table 1). Free parts of the ridge were warmer than the edges between ridge and wall, and the lowest average temperatures were observed at crevices in the attic. Crevices in the ridge showed maximum temperature variation during the course of the day. High variation was also measured in free parts of the ridge, while temperature varied less in crevices in the attic. In the evenings, temperatures fell slowly and quite similarly in each roosting site category.

In July through October (lactation, fledging, prehibernation), on sunny days in the afternoon, temperature was measured directly at the roosting sites of 13 groups of bats comprising 42 individuals altogether. During that time, temperatures in the ridge of the attic normally exceeded $30^{\circ} \mathrm{C}$. The majority of the bats $(45.2 \%)$, however, chose temperatures between $20^{\circ} \mathrm{C}$ and $25^{\circ} \mathrm{C}$ (Table 2). In six of seven cases, when groups of bats were found roosting at temperatures below $25^{\circ} \mathrm{C}$ ( 26 animals), higher temperatures at other roosting sites could be verified. A smaller portion of all individuals $(23.8 \%)$ were found roosting at temperatures between $26^{\circ} \mathrm{C}$ and $30^{\circ} \mathrm{C}$. No bats could be found at

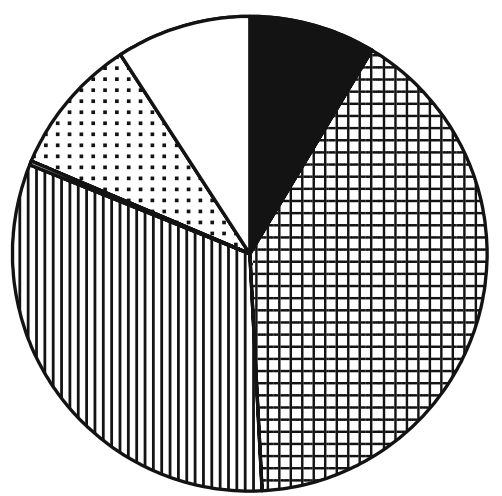

\begin{tabular}{|ll|}
\hline ridge-corner (8,7\%) & ⿴囗十 ridge-open (40,6\%) \\
$\square$ ridge-crevices (31,8\%) & $\square$ attic-open (0,5\%) \\
⿴囗attic-crevices (9,3\%) & $\square$ clock tower $(9,2 \%)$ \\
\hline
\end{tabular}

Fig. 4 Distribution of occupied roosting sites during the day (when bats are at rest) in five maternity colonies ( $N=199$ individuals). Individuals flying or otherwise moving which could not be related to a roosting site were excluded 
Table 1 Maximum/minimum temperatures and temperature variability at four types of roosting sites in five maternity colonies

\begin{tabular}{lcccc}
\hline & T min & T max & Delta T min & Delta T max \\
\hline Ridge-crevices & 13.0 & 44.0 & 4.0 & 27.0 \\
Ridge-open & 14.5 & 42.5 & 4.0 & 21.0 \\
Ridge-corner & 13.5 & 37.5 & 4.0 & 17.0 \\
Attic-crevices & 15.0 & 31.0 & 2.5 & 9.0 \\
\hline
\end{tabular}

$\mathrm{T} \min / \max =$ lowest/highest temperature measured during the study period at any roosting site of the respective site category; deltaT min/ $\max =$ lowest/highest difference in temperature values measured during 1 day $(24 \mathrm{~h})$

roosting sites where the temperature exceeded $32.5^{\circ} \mathrm{C}$ or was below $19.5^{\circ} \mathrm{C}$. That the bats intentionally chose cooler roosts is supported by the fact that $P$. austriacus did not use the clock tower, which warms up very quickly, during summer.

\section{Clustering and thermoregulative behaviour}

P. austriacus bats normally used several roosting sites within an attic simultaneously and often hung scattered over the roost. The proportion of bats found in clusters of dense or loose body contact varied between $37 \%$ and $63 \%$ during seasons: in posthibernation, the majority of the animals $(59 \%)$ were found at their roosting site without body contact to others (Fig. 5). The highest percentage of bats hanging in dense or loose contact was observed during lactation (63\%); however, during pre- and postlactation, the values were similar $(58 \%$ and $56 \%)$. In prehibernation period, more bats were found hanging without any contact again (63\%). The average size of the clusters was always similar throughout the year (three to five individuals) except during lactation when larger clusters (mean 7, maximum 13 bats) occurred.

Emergence behaviour and activity at the roost during the night

We monitored 31 emergences of altogether 359 individuals in four colonies. Altogether, 54\% of the bats left the church

Table 2 Recorded temperatures at the roosting sites of 42 bats

\begin{tabular}{lccc}
\hline Temperature range & Groups of bats & Number of bats & Bats (\%) \\
\hline$<20^{\circ} \mathrm{C}$ & 2 & 7 & 16.7 \\
$20-25^{\circ} \mathrm{C}$ & 5 & 19 & 45.2 \\
$26-30^{\circ} \mathrm{C}$ & 4 & 10 & 23.8 \\
$>30^{\circ} \mathrm{C}$ & 2 & 6 & 14.3 \\
Total & 13 & 42 & 100.0 \\
\hline
\end{tabular}

Data were acquired during lactation, fledging, and prehibernation periods only

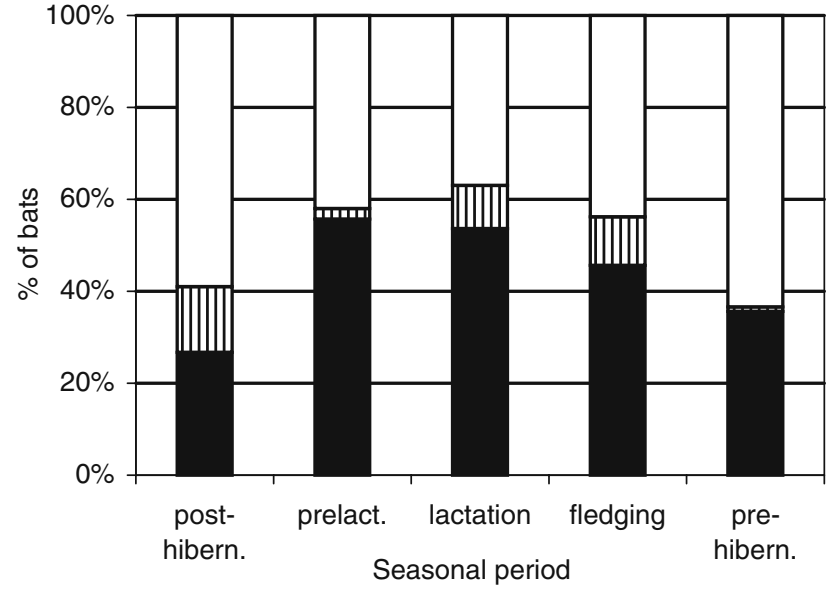

Dense body contact $\mathbb{U}$ Loose body contact $\square$ No body contact

Fig. 5 Body contact of $P$. austriacus bats ( $N=404$ individuals) in three colonies in the course of the study period. $100 \%$ indicate all animals from which data concerning body contact could be taken, including mothers with their offspring

via the attic, $46 \%$ via the clock tower (Fig. 6). However, this pattern was not observed in individual colonies, as bats of one colony always favoured either emerging through the attic or the clocktower. Altogether, the windows of the clock towers, with animals landing on lamellas in the windows and then crawling outside, were used most intensively (41\%). Gaps at the ridges or in the roof and windows in walls were used by $29 \%$ of the bats. Generally, the bats favoured small,
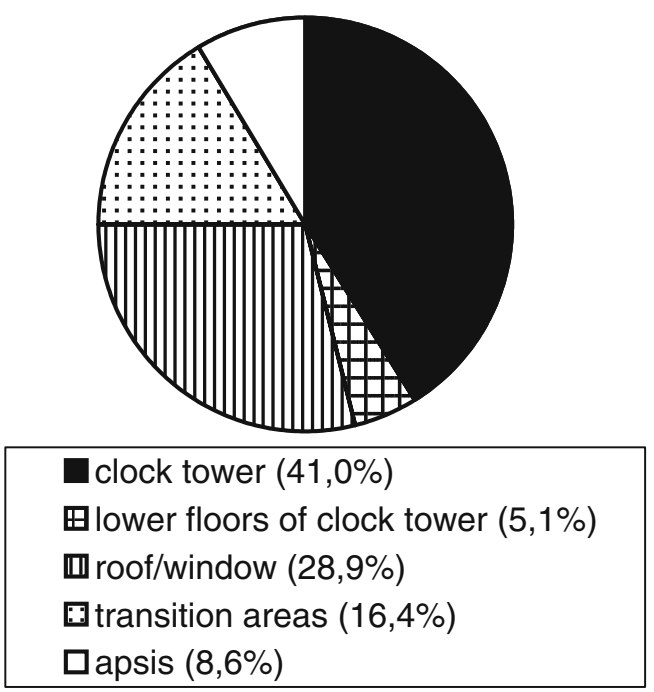

Fig. 6 Percentage use of emergence opening categories in five colonies (30 emergences, 406 bats). Roof/window comprises small gap-like openings in the ridge of the roof or in its surface, as well as windows in the roof or in side walls, wherever existent. Transition areas comprise gaps between two parts of the truss, between truss and walls or between attic and clocktower walls. Bats emerging from unidentified openings ( $29 \%$ of all recorded bats) were excluded 
crevice-like openings which they could not pass without landing ( $80 \%$ of all observed animals). While individual colonies always seemed to make a choice between attic and clock tower, they always used several openings at the same time within that choice. Normally, one was preferred but this favourite entrance sometimes varied between seasons. Especially after the young were born, bats often used the opening closest to the roosting site where they left their offspring.

Emergence time of the median bat varied between seasons and depended on sunset. Emergence always began during dusk, never at darkness, and almost always ended during dusk as well. During postlactation and prehibernation, mean median bat emergence time was significantly earlier (30 min after sunset in both periods) compared to posthibernation, prelactation, and lactation periods $(33,36$, and $39 \mathrm{~min}$, respectively; Mann-Whitney $\mathrm{U}: p=0.03, N=$ 31). The latest start of emergence was $44 \mathrm{~min}$ after sunset, while the earliest bat observed left its roost $6 \mathrm{~min}$ after sunset. The mean duration of the emergence was rather short (22 min, ranging from 6 to $37 \mathrm{~min}$ ), whereby it increased linearly from $16 \mathrm{~min}$ during prelactation to $26 \mathrm{~min}$ in prehibernation period. During prelactation, $72 \%$ of all recorded bats left the roost within the first 9 min after the first bat, compared to only $40 \%$ during lactation. This indicates that more and more females were busy with their offspring in that period. After emergence, the bats flew along the churches and over the graveyards in a height below $6 \mathrm{~m}$ and the majority (64\%) even less than $3 \mathrm{~m}$.

Swarming was observed in the attics before emergence and after return into the attics at dawn and after emergence on the outside. Swarming on the outside prior to return into the attics is assumed, but was not monitored. In the attic, the bats circled around roosting sites and in the whole room. Vespertine swarming started earlier during prelactation (22 min before sunset) than during lactation (13 $\mathrm{min}$ after sunset), and it lasted longer in the first period (57 minutes versus $14 \mathrm{~min}$ ). While swarming inside the roost was observed in all cases, swarming outside the church immediately after emergence was seen less frequently. One colony showed this behaviour only after parturition: many emerging bats were seen swarming around the church during lactation (34\%), fledging (53\%), and prehibernation (46\%). In three of the other colonies, swarming outside the attic after emergence occurred, but only sporadically, throughout the study period. In each case, only one to three of all emerging bats were observed circling shortly over the ridge before leaving. All bats which were observed swarming outside the attic after emergence concentrated over the roof along the ridge. During lactation and fledging, they also swarmed intensively around the entrance openings and at the part of the roof where their roosting site inside the attic was located.
The majority of the bats returned between 120 and 20 min before sunrise throughout the study period. However, there was some activity in the roost during the whole night as well. Sporadically, single bats entered the attic and left again after a short period. In the morning, returning bats circled in the room and especially around their roosting sites before landing. The frequency of this behaviour increased after parturition. The activity in the attic was also considerably higher during the whole night after the young were born. When a bat entered the attic, other bats performed social calls, most intensively when unfledged young were present, calling for their mother each time a bat approached. While no bat was seen for $2 \mathrm{~h}$ after emergence during prelactation, the first animals already returned within $1 \mathrm{~h}$ during lactation period. This illustrates the rising activity in the attics after birth of the offspring.

\section{Discussion}

The birth of the offspring at the end of June changed the behaviour of the bats in several ways: Swarming in the attics before emergence began later and was amended by swarming outside the attics after emergence, while the emergence period lengthened. Nighttime activity inside the attic increased considerably. Apart from the fact that unfledged young were mostly placed in crevices, in some cases even special roosting sites for that purpose were found, located in crevices in the walls. This might reduce the risk of unfledged young falling down from the ridge.

\section{Roosting behaviour}

P. austriacus, originally a cave-dwelling species in the Mediterranean, spread to Central Europe during the Neolithic; this was also shown for other bat species, like Myotis myotis, Myotis emarginatus, or Rhinolophus hipposideros (Horácek 1981; Horácek et al. 2004). As the latter, $P$. austriacus settled in attics in its newly colonised range. However, in comparison to these other species, the grey long-eared bat shows some behavioural and ecological features which indicate a different background for the extension of its range.

P. austriacus bats form smaller clusters (mostly $<7$ bats) and also smaller colonies (maximum number recorded here $=$ 59) than the three other attic-dwelling species (Friemel and Zahn 2004; Güttinger et al. 2001; Zahn and Weiner 2004). With respect to thermoregulation, small cluster sizes are suboptimal (Audet 1992), and small colonies cannot increase the roost temperature, this being possible for other species (Tuttle and Stevenson 1982) forming colonies of several 1,000 individuals (which even may consist of several species (Güttinger et al. 2001; König and König 1961)). 
Corresponding to these behavioural differences, the preferred roosting site temperature of the species was comparatively low. During daytime, most individuals were observed roosting at temperatures between $20^{\circ} \mathrm{C}$ and $25^{\circ} \mathrm{C}$, even if warmer spots were available. The other Central European bat species inhabiting buildings prefer temperatures between $25^{\circ} \mathrm{C}$ and $34^{\circ} \mathrm{C}$ (Kayikcioglu and Zahn 2004; Zahn and Henatsch 1998). It might be, that the use of crevices, which seems to be typical in P. austriacus both for attics and caves (Horácek et al. 2004; Horácek 1975; Braun and Häussler 2003; Rudolf 2004) compensates for the small colony size and the lower roost temperature, because the limited air exchange and the possibility to form clusters in small niches reduce energy loss. Consequently, crevices were used most intensively during pregnancy and lactation when bats avoid torpor because growth of the embryo is slowed down when the metabolism is reduced (Audet and Fenton 1988; Güttinger et al. 2001). The comparatively large cluster sizes observed during lactation correspond to that fact as well.

In respect of these low thermal requirements, the availability of warm summer roosts may have played a less important role for the extension of the distribution range of $P$. austriacus than in other species. The absence of M. myotis, M. emarginatus, and $R$. hipposideros from Central Europe was probably caused by unsuitable nursery roosts (Horácek 1981) rather than by limited foraging areas: Europe was a typical woodland before being changed by humans, and therefore held good conditions for the three species mainly foraging in woodland (Güttinger et al. 2001; Bontadina et al. 2002; Krull et al. 1991). In case of $P$. austriacus, however, which prefers more open landscapes as foraging habitats (Kiefer and Veith 1998a; Kiefer and Veith 1998b; Flückinger and Beck 1995; Rudolf 2004), the new, open landscape created by human activity may have been the key factor for the extension of its range.

\section{Advices for monitoring and observation}

Our study shows that determination of colony sizes is difficult in this species. Between $24 \%$ and $50 \%$ of the bats leaving the attic in the evening were not spotted in the roost before. During visits to the roosts, visible bats often moved into hiding in reaction to the disturbance, and crevices were generally favoured before $5 \mathrm{p}$.m. Therefore, the colony sizes cannot be determined exactly by counting bats in the roosts. Spotting at least the majority of the colony members inside the roost is most likely during visits in the evening, when more bats hang freely visible (1-2 $\mathrm{h}$ before emergence, but before swarming starts), in August on warm days.

Counting of emerging bats is a more suitable method to determine reliable colony sizes, but often, two or more observers will be needed because more than one emergence opening may be used by the bats, and because small emergence openings (e.g. at ridges) may be difficult to detect. Additional use of light barriers at well-known openings would surely prove helpful. Generally, the bats emerge approximately $30 \mathrm{~min}$ after sunset, and within $25 \mathrm{~min}$, most individuals have left. To assess the numbers of adults, counts should be conducted in early or mid-July. However, even during good weather conditions, the numbers of emerging bats varied considerably in our study, indicating that not all individuals are present in the roost each day. In August, an increasing proportion of juveniles joined the emergence before the emigration of adults began in September.

The sensitivity of the bats also made observations of diurnal behaviour inside the attic quite difficult (during the night, however, the bats cared much less about the observer). For further studies, the use of an infrared video camera in the roost is, therefore, recommended.

\section{Conservation aspects}

For renovation works in buildings hosting colony roosts, the recommended time schedule differs from those for other species. $P$. austriacus arrives and leaves comparatively late in the summer roosts. During our study, the bats arrived at the end of April or in early May, and babies were not found before late June, which is similar to the dates given for the Czech Republic (Horácek 1975; Horácek et al. 2004) and Hesse (Fuhrmann 1994) as well as the western part of Germany (Kiefer 1996). The last bat emerging in the evening was recorded on 23 October and Horácek (1975) found bats in summer roosts until November. Other atticdwelling bat species occurring in the study region appear earlier (e.g. Myotis myotis (Güttinger et al. 2001)) or leave their summer roost already in August (e.g. Myotis emarginatus (Friemel and Zahn 2004)) or September (e.g. Rhinolophus hipposideros (Zahn and Weiner 2004). In the case of $P$. austriacus, renovation works should not start before November, but may continue until the end of March. Since a part of the colony may be present in the roost during late autumn or even winter (Fuhrmann 1994), we recommend excluding the bats from the roost during warm periods in early October (when the animals emerge for foraging) before the renovations begin. If this is not possible, the presence of bats hidden in crevices in the roof, the wall, or in beam constructions has to be assumed.

$P$. austriacus frequently used the windows of clock towers for emergence. The animals landed on the lamellas in the windows and crawled outside. Therefore, they can be affected by gratings against doves and by doors installed between attic and tower for fire prevention. Even more did the animals use gaps in the ridge or in the surface of the 
roof for emergence. Openings like that often indicate a damage of the roof and are normally lost during renovation work. To identify such hidden entrances, several observations during emergence or in the morning when bats return to the roosts are necessary.

Outside the roost, the majority of the monitored bats flew at heights below $3 \mathrm{~m}$. Bauerova (1980) observed foraging animals at a height of 2-5 $\mathrm{m}$ and Steinborn (1984) reports even $1-3 \mathrm{~m}$ low flights. Therefore, this species is highly endangered by traffic when crossing streets and roads. Haensel and Rackow (1996) mention 11 known cases of $P$. austriacus bats killed by traffic $(7.5 \%$ of all registered bat casualties). Other cases are reported by Kiefer et al. (1994). If new roads are planned near roosts of $P$. austriacus, measures to minimise the risk for the animals should be considered.

Acknowledgements The authors wish to thank Mrs. Strasser, Mr. and Mrs. Heiger, Mr. Flammensbeck, Mrs. Mayr and Mrs. Angermaier, the sacristans of the parishes hosting the five monitored maternity colonies of Plecotus austriacus, for kindly providing all help required for the realisation of this study. Furthermore, we would like to thank Frank Arnoldi and Dr. Manfred Scheunert for their help with the counts inside and outside the attics, as well as Dr. Ryan Oyama for proofreading the English version of the manuscript.

\section{References}

Audet D (1992) Roost quality, foraging and young production in the mouse-eared bat Myotis myotis: a test of the ESS model of group size selection. Ph.D. Diss., York Univ., Ontario

Audet D, Fenton MB (1988) Heterothermy and the use of torpor by the bat Eptesicus fuscus (Chiroptera: Vespertilionidae): a field study. Physiol Zool 61:197-204

Bauerova Z (1980) Contribution to the trophic ecology of the grey long-eared bat, Plecotus austriacus. Folia Zool 31(2):113-122

Bontadina F, Schofield H, Naef-Daenzer B (2002) Radio-tracking reveals that lesser horseshoe bats (Rhinolophus hipposideros) forage in woodland. J Zool Lond 258:281-290

Braun M, Häussler U (2003) Graues Langohr Plecotus austriacus (Fischer 1829). In: Braun M, Dieterlen F (eds) Die Säugetiere Baden-Württembergs Band 1. Eugen Ulmer, Stuttgart, pp 474-483

Bundesamt für Naturschutz (1998) Rote Liste gefährdeter Tiere Deutschlands. Schriftenr Landschpfl Naturschutz 55:434pp

Flückinger FP, Beck A (1995) Observations on the habitat use for hunting by Plecotus austriacus (Fischer 1829). Myotis 32 (33):121-122

Friemel D, Zahn A (2004) Wimperfledermaus (Myotis emarginatus). In: Bayerisches Landesamt für Umweltschutz (ed) Fledermäuse in Bayern. Eugen Ulmer, Stuttgart, pp 166-176

Fuhrmann M (1994) Graues Langohr, Plecotus austriacus (Fischer 1829). In: Arbeitsgemeinschaft für Fledermausschutz in Hessen (ed) Die Fledermäuse Hessens. Manfred Hennecke, RemshaldenBuoch, pp 74-75

Güttinger R, Zahn A, Krapp F, Schober W (2001) Myotis myotisGroßes Mausohr. In: Krapp F (ed) Handbuch der Säugetiere Europas Band 4. Fledertiere, Teil 1. Chiroptera 1, Aula, Wiebelsheim, pp 123-207

Haensel J, Rackow W (1996) Fledermäuse als Verkehrsopfer-ein neuer Report. Nyctalus 6(1):29-47

Hanak V (1969) Ökologische Bemerkungen zur Verbreitung der Langohren (Gattung Plecotus Geoffroy 1818) in der Tschechoslowakei. Lynx 6:57-66

Horácek I (1975) Notes on the Ecology of Bats of the Genus Plecotus (Geoffroy 1818) (Mammalia: Chiroptera). Vest Cs Spolia Zool 39 (3): $195-210$

Horácek I (1981) Comparative notes on the population structure in several European bat species. Myotis 18(19):8-53

Horácek I, Dulic B, Bogdanowicz (2004) Plecotus austriacus (Fischer 1829)_Graues Langohr. In: Niethammer J, Krapp F (eds) Handbuch der Säugetiere Europas 4: Fledertiere, Teil II: Chiroptera II. Eugen Ulmer, Kempten, pp 1001-1049

Kayikcioglu A, Zahn A (2004) High temperatures and the use of satellite roosts in Rhinolophus hipposideros. Mammalian Biology (Z f Säugetierkd) 69:337-341

Kiefer A (1996) Untersuchungen zu Raumbedarf und Interaktionen von Populationen des Grauen Langohrs (Plecotus austriacus FISCHER, 1829) im Naheland. Diploma Thesis, JohannesGutenberg-Univ, Mainz

Kiefer A, Veith M (1998a) Untersuchungen zu Raumbedarf und Interaktionen von Populationen des Grauen Langohrs, Plecotus austriacus (Fischer 1829), im Nahegebiet. Nyctalus 6(5):531

Kiefer A, Veith M (1998b) Saisonale thermoregulatorische Hangplatzwahl in einem Sommer- und Winterquartier beim Grauen Langohr, Plecotus austriacus (Fischer 1829) (Chiroptera, Vespertilionidae). Nyctalus 6(5):532

Kiefer A, Merz H, Rackow W, Roer H, Schlegel D (1994) Bats as traffic casualties in Germany. Myotis 32:215-220

König C, König J (1961) Zur Ökologie und Systematik südfranzösicher Fledermäuse. Bonner zool Beitr 12:189-229

Krull D, Schumm A, Metzner W, Neuweiler G (1991) Foraging areas and foraging behaviour in the notch-eared bat Myotis emarginatus (Vespertilionidae). Behav Ecol Sociobiol 28:247-253

Rudolf BU (2004) Graues Langohr Plecotus austriacus (Fischer 1829). In: Meschede A, Rudolph BU (eds) Fledermäuse in Bayern. Eugen Ulmer, Stuttgart, pp 333-339

Stebbings RE (1970) A comparative study of Plecotus auritus and Plecotus austriacus (Chiroptera, Vespertilionidae) inhabiting one roost. Bijdr Dierkde 40(1):91-94

Steinborn G (1984) Graues Langohr - Plecotus austriacus (Fischer 1829). In: Schröpfer R, Feldmann R, Vierhaus H (eds) Die Säugetiere Westfalens. Abh Westf Mus Naturkd Münster 46 (4):116-119

Tuttle MD, Stevenson D (1982) Growth and survival of bats. In: Kunz TH (ed) Ecology of bats. Plenum Press, New York, pp 105-150

Zahn A, Henatsch B (1998) Bevorzugt Myotis emarginatus kühlere Wochenstubenquartiere als Myotis myotis? Mammalian Biology (Z f Säugetierkd) 63:26-31

Zahn A, Weiner P (2004) Kleine Hufeisennase (Rhinolophus hipposideros). In: Bayerisches Landesamt für Umweltschutz (ed) Fledermäuse in Bayern. Eugen Ulmer, Stuttgart, pp 111-126 